\title{
Physician factors associated with medical errors in Norwegian primary care emergency services. Based on a case - control study with patient complaints as an outset.
}

Research article

Keywords:

Posted Date: February 15th, 2021

DOl: https://doi.org/10.21203/rs.3.rs-23532/v2

License: (1) This work is licensed under a Creative Commons Attribution 4.0 International License. Read Full License 


\section{Abstract}

The authors have requested that this preprint be withdrawn due to author disagreement.

\section{Full Text}

The authors have withdrawn this preprint from Research Square. 